\title{
Ultrastructural damage in coffee seeds exposed to drying and to subzero $\left({ }^{\circ} \mathrm{C}\right)$ temperatures
}

\author{
Stefânia Vilas Boas Coelho1 (iD, Sttela Dellyzete Veiga Franco da Rosa² (D), Aline da Consolação Sampaio Clemente ${ }^{3}$ (D), \\ Laura Nardelli Castanheira Lacerda ${ }^{1}$ (D), Luciano Coutinho Silva ${ }^{4}$ (D), Tatiana Botelho Fantazzini ${ }^{\text {(D) }}$, \\ Fernando Augusto Sales Ribeiro' ${ }^{1}$, Elisa de Melo Castro ${ }^{1}$ (D)
}

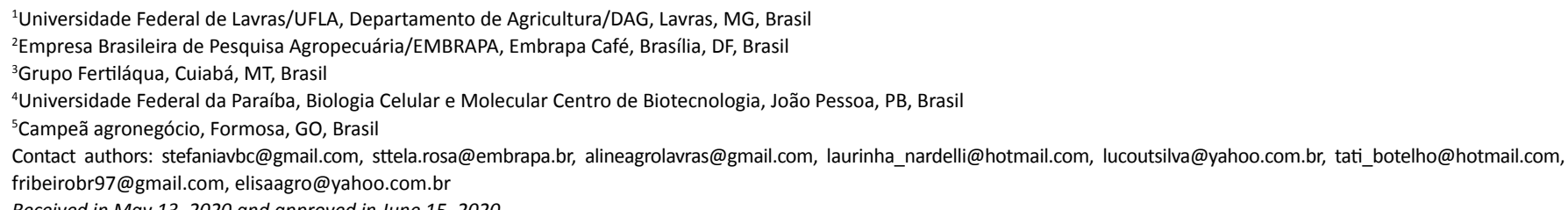

fribeirobr97@gmail.com, elisaagro@yahoo.com.br

Received in May 13, 2020 and approved in June 15, 2020

\section{ABSTRACT}

During drying and freezing, protective mechanisms act to maintain seed physiological quality. Some of these mechanisms contribute to the integrity of cell membranes. The damage caused to cell membranes due to cell stress can be seen in ultrastructural studies, comparing these results to those of physiological evaluation. The aim of this study was to investigate ultrastructural changes in endosperm cells of coffee seeds brought about by drying and by exposure to low temperatures. Seeds of Coffea arabica were dried in silica gel to moisture contents of 40, 20, and $5 \%$ (wb) and brought to equilibrium at temperatures of $10,-20$, and $-86^{\circ} \mathrm{C}$. Germination, vigor, and tetrazolium tests were performed for evaluation of seed physiological quality. Ultrastructural damage was analyzed by scanning electron microscopy. Coffee seeds with $40 \%$ moisture content have whole, swollen, and expanded cells, with a filled lumen and without signs of damage. The physiological and ultrastructural quality of seeds exposed to below zero temperatures with $40 \%$ moisture content is compromised. They have null germination and empty cells, indicating leakage of cell content. Drying of coffee seeds leads to uniform contraction of inner cell content. Drying of coffee seeds to $5 \%$ moisture content leads to intense contraction of cell volume, with physiological and ultrastructural damage.

Key words: Scanning electron microscopy; desiccation tolerance; Coffea arabica L.

\section{INTRODUCTION}

Conservation of coffee seeds for long periods continues to be a challenge for producers and plant breeding programs due to coffee seed sensitivity to desiccation. Seeds of the species Coffea arabica $\mathrm{L}$. are classified as intermediate in relation to desiccation tolerance (Ellis; Hong; Roberts, 1990) because they tolerate a certain degree of dehydration, but their longevity is reduced, mainly due to a progressive process of deterioration and to low tolerance to low storage temperatures.

Seeds are stored to preserve genetic resources; the purpose is to maintain the integrity and viability of plant structures over long periods. The conservation of orthodox seeds in germplasm banks consists of storing them at low moisture contents, around $5 \pm 2 \%$, at a temperature of $-20{ }^{\circ} \mathrm{C}$ (Umarani; Aadhavan; Faisal, 2015). One alternative for drying seeds is the use of silica gel, which offers the advantage of being able to achieve very low moisture contents (José et al., 2011). Although the temperature of $-20{ }^{\circ} \mathrm{C}$ provides for preservation of seed quality for a longer period of time, there is a critical and ideal moisture content indispensable for preserving quality for each different storage temperature (Walters, 2015). For seeds with recalcitrance characteristics, such as coffee, conservation is done through germplasm banks in situ (Dussert et al., 2012).

The primary factors that can be manipulated and controlled to minimize deterioration during storage are moisture content of the seeds and air temperature (Figueiredo et al., 2017). The use of ultra-low temperatures during storage has become a potential technique for long-term conservation of seeds, due to reduction of metabolism to levels so low that all the metabolic and biochemical processes are significantly reduced and deterioration is halted (Pammenter; Berjak, 2014). To achieve that state, seed moisture content is undoubtedly the critical factor for success in the technique. Upon freezing, water expands and forms sharp and irregular ice crystals (Wesley-Smith et al., 2015), which may instantly kill the seed during the freezing and/or thawing process (Dussert et al., 2012). The great challenge in use of ultra-low temperatures is achieving freezing without the formation of ice crystals within the cells.

Storage of coffee seeds at ultra-low temperatures has been investigated (Coelho; Rosa; Fernandes, 2017; Figueiredo et al., 2017) and various advances have already been made. Techniques are being adjusted to ensure the conservation of different species and cultivars in a secure way. 
Transformations of a chemical, physical, physiological, and biochemical nature can occur during drying of coffee seeds (Santos; Chalfoun; Pimenta, 2009). The stress condition imposed by drying can lead to disorganization of cell membranes, which are particularly susceptible to structural damage. Ultrastructural analyses in cell tissues are used to identify such damage and have been considered important tools for understanding changes in seed physiological quality (Silva et al., 2007; Saath et al., 2010). Maintaining cell integrity throughout the drying process mainly depends on the rate of water removal, the final moisture content reached, and the storage temperature of the seeds. This was confirmed by Saath et al. (2010), who investigated the effects of the drying process on the cell structure of coffee beans and observed that the drying temperature and moisture content attained affected membrane integrity.

Ultrastructural analyses of cell membranes and cell walls of coffee seeds can contribute to understanding the processes of loss of quality during drying and storage at below zero $\left({ }^{\circ} \mathrm{C}\right)$ temperatures. The studies found up to this time on coffee seeds do not associate changes in seed physiological quality with the results of such analyses. Thus, the aim of this study was to investigate the ultrastructural changes in endosperm cells of coffee seeds brought about by drying and exposure to low temperatures, comparing these results to those of physiological evaluation.

\section{MATERIAL AND METHODS}

Seeds from the 2012/2013 crop season of Coffea arabica L., cv. Catuaí Amarelo IAC 62, were used. The fruit was collected on the Procafé Experimental Farm in the municipality of Varginha, Minas Gerais, Brazil, at an altitude of $980 \mathrm{~m}$, with a highland tropical climate $(\mathrm{Cwb})$, according to the Köppen classification.

The work was carried out in the Seed Analysis Laboratory, of the Department of Agriculture, and in the Laboratory of Electronic Microscopy and Ultrastructural Analysis (LME), located in the Department of Phytopathology, at the Universidade Federal de Lavras (UFLA).

Ultrastructural studies were carried out of seeds obtained from fruit selectively harvested in the cherry maturity stage from the middle branches of the plants and in the middle parts of the branches. After harvest, the fruit was once more selected for uniformity of the maturity stage, and it was mechanically pulped. The mucilage was then removed from the seeds through fermentation in water for 24 hours and the seeds were pre-dried in the shade for removal of surface moisture. Uniform size was achieved by using the seeds retained in a sieve with a circular screen $n^{\circ} .20 / 64$.

To evaluate the role of moisture content in tolerance to exposure to above zero and below zero temperatures after desiccation, the seeds were dried to moisture contents of $40 \%$, $20 \%$, and $5 \%$ (wet basis) in environments with controlled temperatures. The seeds were dried by placing them in a single layer on a screen in a gerbox (plastic box), with activated silica gel below the screen. As drying proceeded, the silica was switched before there was a change in its color, which would indicate an increase in relative humidity.

The containers with the silica gel and the seeds were placed in BOD chambers at a constant temperature of $25^{\circ} \mathrm{C}$. The loss of water during drying was monitored by continual weighing on a precision balance $(0.001 \mathrm{~g}$ resolution) until the seeds reached the desired moisture contents.

The seeds with different moisture contents were then placed in hermetically sealed packaging at temperatures of $10,-20$ and $-86{ }^{\circ} \mathrm{C}$ for 24 hours. After equilibrium at the temperatures mentioned, the seeds were evaluated physiologically and ultrastructurally.

To proceed with the evaluations, the seeds exposed to temperatures of -20 and $-86{ }^{\circ} \mathrm{C}$ were thawed in a water bath for 2 minutes at $40{ }^{\circ} \mathrm{C}$ according to the method of Coelho, Rosa and Fernandes (2017); they were rapidly removed from their respective packaging and immersed directly in the water bath. After that, they were dried on paper toweling and their parchment was removed manually. Seeds submitted to a temperature of $10{ }^{\circ} \mathrm{C}$ did not undergo the thawing process.

The moisture content of the seeds was determined by drying them in a laboratory oven at $105^{\circ} \mathrm{C}$ for 24 hours (Brasil, 2009), and results were expressed in percentage, based on wet weight of the seeds.

\subsection{Physiological analyses}

The germination test was carried out with four replications of 25 seeds for each treatment, sown in sheets of germination paper, and moistened with water in the amount of 2.5 times the weight of the dry paper. The seeds were kept in a germinator at a constant temperature of $30^{\circ} \mathrm{C}$, and the percentage of normal seedlings was evaluated after 30 days, following the directives of the RAS (Brasil, 2009). In the germination test, determination was also made of the percentage of strong normal seedlings at 30 days (seedlings were regarded as strong if they had a hypocotyl arch of three centimeters or more), percentage of seedlings with expanded cotyledonary leaves at 45 days after sowing, and seedling dry matter.

The seedlings from the germination test was submited to determination of seedling dry matter, the hypocotyl-radicle axes of the normal seedlings were isolated, placed in paper bags, and dried in an air circulation laboratory oven at $60{ }^{\circ} \mathrm{C}$ for 5 days. After this period, the dry matter of the roots and above ground parts of the seedlings was determined, and the results were expressed in milligrams per seedling.

The tetrazolium test was conducted using four replications of 10 seeds, which were soaked in distilled water 
for a period of 48 hours at $30{ }^{\circ} \mathrm{C}$ (Clemente et al., 2011). After soaking, the embryos were removed with the aid of a scalpel, avoiding damage. Embryos were stained by immersing them in a $0.5 \%$ tetrazolium solution in the absence of light for a period of 3 hours at $30^{\circ} \mathrm{C}$. They were then evaluated and the results were expressed in percentage of viable embryos.

\subsection{Ultrastructural analyses}

Five seeds were removed at random from each sample and used for ultrastructural analyses. The seeds were manually cut to obtain transverse sections of the endosperms of approximately $1 \mathrm{~mm}$ thickness, which were immersed in modified Karnovsky fixative solution $(2.5 \%$ glutaraldehyde, $2.0 \%$ paraformaldehyde, $0.05 \mathrm{M}$ cacodylate buffer, $\mathrm{pH}$ 7.2). The samples were removed from the solution and cut longitudinall, with the aid of a scalpel. The fragments obtained were immersed in $1 \%$ osmium tetroxide solution (3 drops) and water for one hour. They were then washed three times in distilled water and subsequently dehydrated in acetone series $(25,50,75,90$, and $100 \%$, three times) and transferred to a critical point dryer. The specimens obtained were mounted on aluminum supports (stubs), covered with gold, and observed in a scanning electron microscope LEO EVO 40 XVP. Several images of each sample were generated and registered digitally under working conditions of $20 \mathrm{kv}$ and work distance between 7 and $15 \mathrm{~mm}$.

\subsection{Statistical analysis}

A completely randomized statistical design was used for analysis of physiological data, in a $3 \times 3$ factorial arrangement consisting of three moisture contents $(5,20$, and $40 \%)$ and three exposure temperatures $\left(10,-20\right.$, and $\left.-86{ }^{\circ} \mathrm{C}\right)$, with four replications. Analysis of variance was conducted on the data through the statistical program SISVAR (Ferreira, 2011), and the means were compared by the Scott-Knott test at the level of $5 \%$ probability.

\section{RESULTS}

Figure 1 represents the drying curve of coffee seeds. As seeds lost moisture, the drying rate decreased, which is indicated by the reduced slope of the straight line to achieve moisture contents of 20 and $5 \%$ wb (Figure 1). Seeds with initial moisture of $42 \% \mathrm{wb}$ under drying in silica gel took 4 hours to reach $40 \%$ moisture, 55 hours to reach $20 \%$ moisture, and 577 hours to reach $5 \%$ moisture, with a mean drying rate of $0.062 \%$ per hour.

The results of the physiological tests performed on coffee seeds, with 40, 20 and 5\% and exposed for 24 hours to the temperatures of $10,-20$, and $-86^{\circ} \mathrm{C}$ are shown in Figure 2.

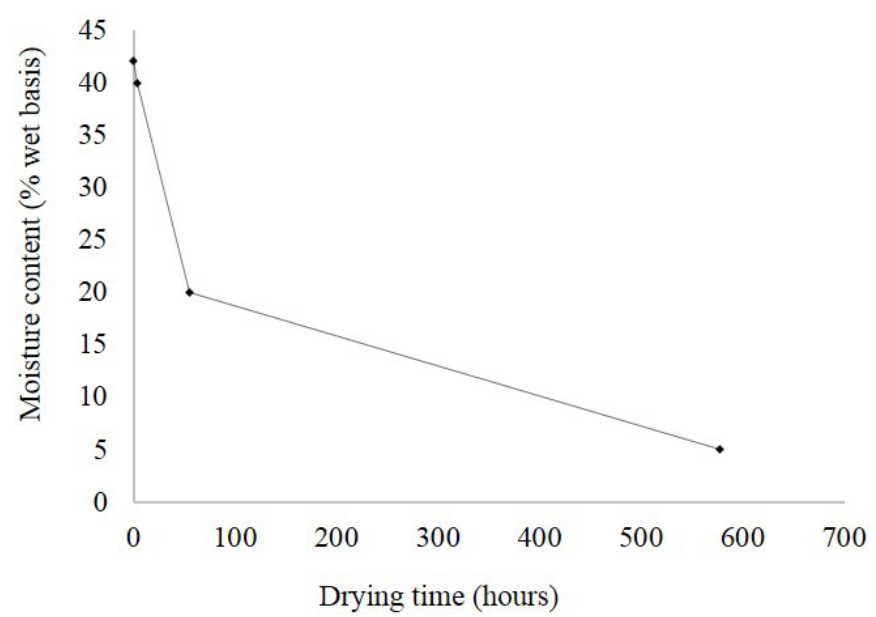

Figure 1: Drying curve of Coffea arabica L. seeds in silica gel.

According to the results of the germination test (Figure 2A), the moist seeds, i.e., those with $40 \%$ moisture content, only survived under the storage temperature of $10^{\circ} \mathrm{C}$. When these seeds were exposed to -20 and $-86^{\circ} \mathrm{C}$, there was no germination percentage. This may have occurred due to damage caused by ice crystals since the seeds were exposed to ultra-low temperatures in a hydrated state. The seeds dried to $20 \%$ moisture content exhibited high germination after storage at temperatures of 10 and $-20{ }^{\circ} \mathrm{C}$ (Figure 2A), with normal seedling percentages near $80 \%$. At this same moisture content, $20 \%$, the seeds exposed to the lowest temperature, $-86{ }^{\circ} \mathrm{C}$, exhibited a lower value of germination compared to the seeds exposed to the temperature of $-20{ }^{\circ} \mathrm{C}$. Drying to $5 \%$ moisture caused a drastic reduction in seed physiological quality, regardless of the temperature to which they were exposed, according to the results of the germination test (Figure 2A).

In relation to the other evaluations of seed physiological quality, vigor indicators (Figure 2C, D, E, and F), a tendency similar to that of the germination test was observed. The seeds with $40 \%$ moisture content did not survive when exposed to temperatures below zero. Drying to moisture content of $5 \%$ is extremely harmful to coffee seed vigor. The moisture content of $20 \%$ seems to have been the least harmful to coffee seeds when they were exposed to the temperatures studied over the period of 24 hours. The seeds better tolerate the temperature of $-20{ }^{\circ} \mathrm{C}$ compared to the temperature of $-86{ }^{\circ} \mathrm{C}$ (Figure 2).

An interesting fact was found in the tetrazolium test, in which even though the seeds did not survive reduction to $5 \%$ moisture content, the embryos extracted from these seeds were viable at this same moisture content, which varied according to the temperature they were exposed to (Figure 2B). 

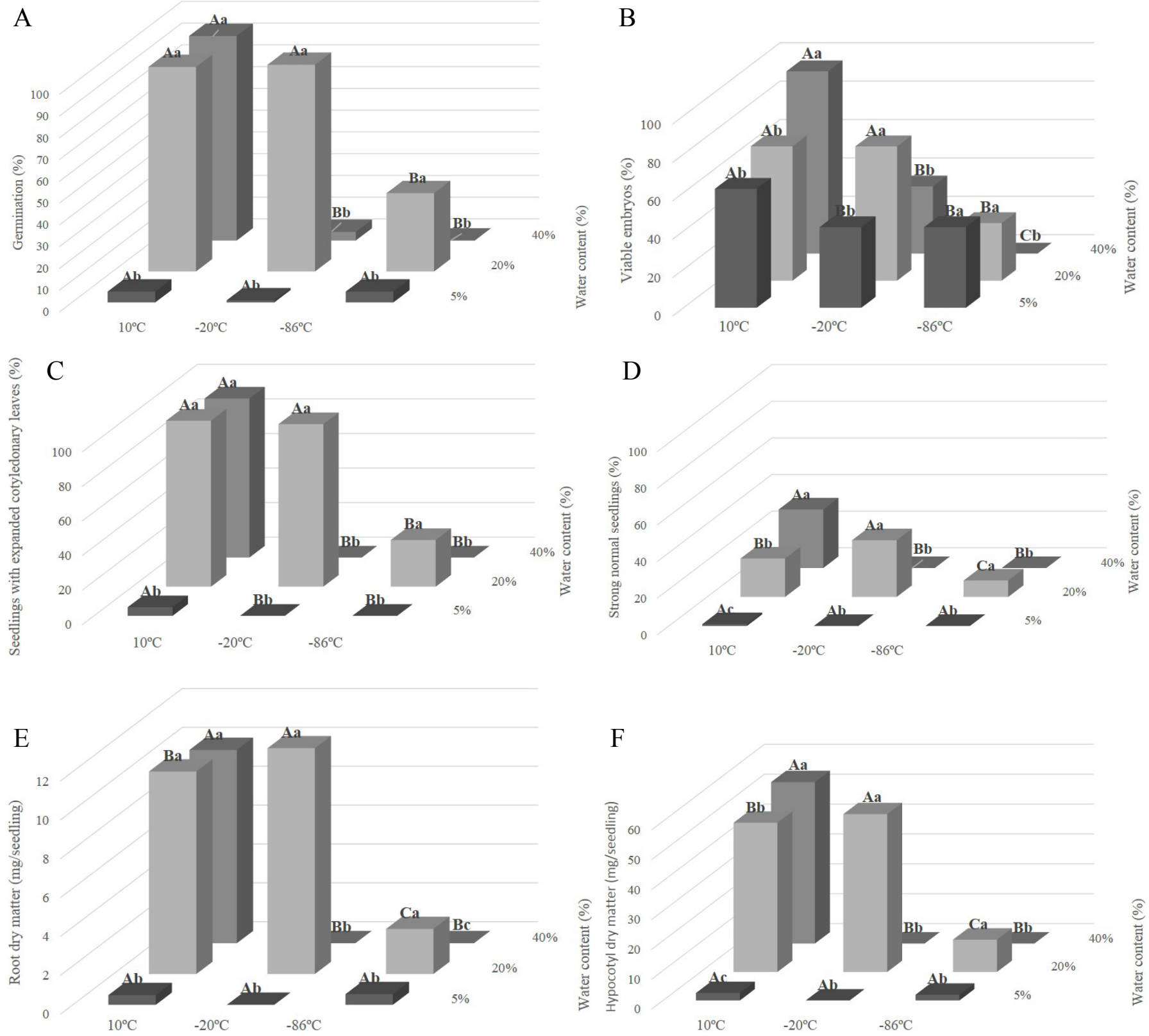

Figure 2: Influence of moisture content and temperature on the results of germination $(A)$, viable embryos in the tetrazolium test (B), seedlings with expanded cotyledonary leaves (C), strong normal seedlings (D), root dry matter (E) and hypocotyl dry matter (F) of Coffea arabica L. seeds. Uppercase letters compare temperatures to which seeds were exposed within the same moisture content. Lowercase letters compare moisture contents within the same temperature. Mean values followed by the same letter do not differ from each other by the Scott-Knott test at $5 \%$ probability.

The results of ultrastructural analyses in coffee seeds exposed to different temperatures after drying to different moisture contents are presented in Figure 3. Figure 3A illustrates the endosperm cells of moist coffee seeds, with $40 \%$ moisture content, kept for 24 hours at $10^{\circ} \mathrm{C}$. It shows that the cell content largely remained within the cells, as they were not subjected to any stress situation. The cells also appear swollen and expanded, and intercellular spaces are not very visible. However, Figure 3B and $3 \mathrm{C}$ show a greater number of empty cells, due to rupture of plasmatic membranes and leakage of cell content, possibly brought about by exposure to low temperature, since in these samples the seeds were exposed to temperatures of -20 and $-86^{\circ} \mathrm{C}$ in a moist state, at $40 \%$ moisture content.

The microscopic aspects of seeds that were dried to $20 \%$ moisture content and kept at $10{ }^{\circ} \mathrm{C}$ are shown in Figure 3D. The inner content of the endosperm cells is contracted, probably due to the drying process applied to the coffee seeds. Although the cell volume contracted, the integrity of the cell structure was maintained. In seeds with $20 \%$ moisture content exposed to 


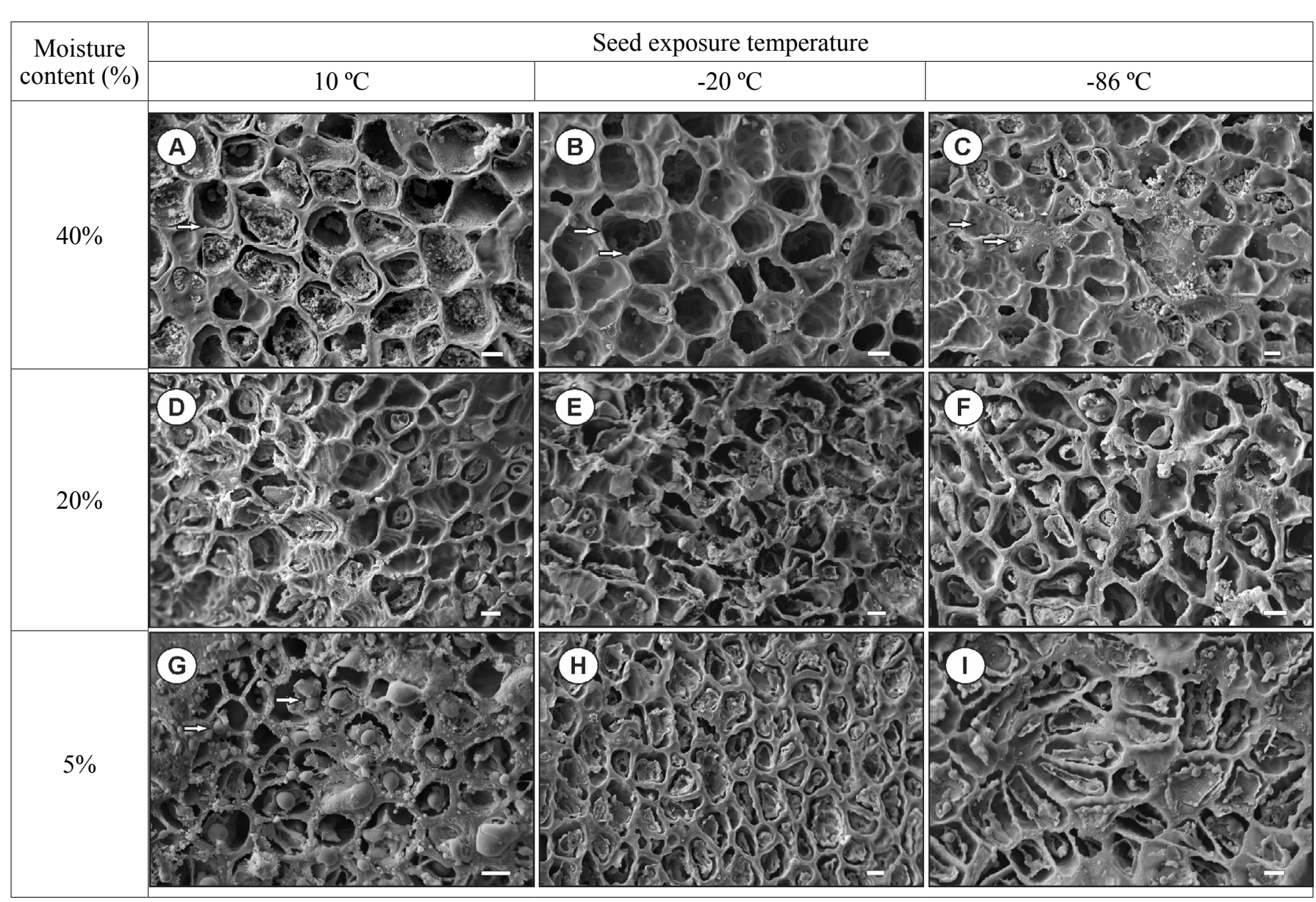

Figure 3: Scanning electron microscopy of the endosperms of Coffea arabica L. seeds dried to different moisture contents (40\%, $20 \%$, and $5 \%$ ) and brought to equilibrium at different above and below zero temperatures $\left(10,-20\right.$, and $\left.-86^{\circ} \mathrm{C}\right)$. Scale bars: $20 \mu \mathrm{m}$.

temperatures of -20 and $-86^{\circ} \mathrm{C}$ (Figures $3 \mathrm{E}$ and $3 \mathrm{~F}$ ), leakage of cell content did not occur, probably indicating that ice crystals did not form and that the moisture content within the cells was well adjusted, without free water subject to freezing that would have damaging ultrastructural consequences.

In coffee seeds dried to 5\% moisture content and stored at $10{ }^{\circ} \mathrm{C}$ (Figure $3 \mathrm{G}$ ), intense contraction of cell volume was observed compared to seeds dried to $20 \%$ (Figure 3D). The presence of oil globules is also evident in this figure, indicating leakage from the cytoplasm through loss of integrity of the plasmatic membrane.

In spite of exposure of the seeds dried to $5 \%$ moisture content to temperatures below zero ${ }^{\circ} \mathrm{C}$, there was no leakage of cell content; the lumen was filled, though contracted (Figures $3 \mathrm{H}$ and 3I). This can be explained due to the low moisture content, $5 \%$, of the seeds in these samples.

\section{DISCUSSION}

Seeds with $40 \%$ moisture content, when were exposed to -20 and $-86{ }^{\circ} \mathrm{C}$, there was no germination percentage. Damage caused by exposure to or storage at ultra-low temperatures are mainly due to the formation of ice crystals in the intracellular medium (Pammenter; Berjak, 2014). Ice crystals are formed when the moisture content of the cells is not correctly adjusted, thus leading to crystallization of water molecules (Wesley-Smith et al., 2014). The moisture content of the seeds at the time of storage is one of the most important factors because it determines seed survival after exposure to ultra-low temperatures (Bhandari; Nayyar, 2014).

The survival of seeds with $20 \%$ moisture under negative temperatures may be related to a lower free water content in the cells. Drying of seeds to a moisture content at which there is no freezable water in the cells can prevent formation of intracellular ice crystals (Wesley-Smith, et al., 2014). According to Wesley-Smith, et al. (2015), when hydrated seeds are frozen, ice crystals may form; cell membranes may rupture and cell content may leak out, which is lethal to cells. In the present study, seeds dried to $20 \%$ moisture and subjected to $-20{ }^{\circ} \mathrm{C}$ showed germination averages above $70 \%$.

Drying to $5 \%$ moisture caused a drastic reduction in seed physiological quality, regardless of the temperature to which they were exposed, according to the results of the germination test (Figure 2A). According to Ellis, Hong and 
Roberts (1990), coffee seeds are classified as intermediate in relation to tolerance to drying and to their response to storage. Thus, these seeds do not tolerate drying to levels below $10 \%$ and also do not tolerate storage at negative temperatures.

An interesting fact was found in the tetrazolium test, in which even though the seeds did not survive reduction to $5 \%$ moisture content, the embryos extracted from these seeds were viable at this same moisture content, which varied according to the temperature they were exposed to (Figure 2B). These results clearly show the greater sensitivity of the endosperms in relation to the embryos when the seeds are dried to lower moisture contents and exposed to below zero temperatures, which corroborates other authors (Figueiredo et al., 2017; Coelho; Rosa; Fernandes, 2017).

The changes brought about by reduction in moisture content and exposure to ultra-low temperatures in the structures of the cell membranes of the coffee endosperm are shown in Figure 3. Both the moisture content and the temperatures seeds were exposed affected the resistance and structural predisposition of the cell walls in these structures.

Saath et al. (2010) analyzed the effect of different drying methods on integrity of cell walls and plasmatic membranes of coffee beans and observed compromised structure of endosperm cells at moisture contents between 30 and 20\% (wb). These authors also observed that in moist coffee beans, the cell wall remained whole and the intercellular space empty, corroborating the results found in the present study.

In coffee seeds dried to $5 \%$ moisture content and stored at $10{ }^{\circ} \mathrm{C}$ (Figure $3 \mathrm{G}$ ), intense contraction of cell volume was observed. The ultrastructural damage observed in these seeds corroborates the physiological results. Saath et al. (2010) also observed the presence of salient points in the form of drops, referring to the concentration of oils in the inner perimeter of the membrane in coffee beans at lower moisture contents.

In spite of exposure of the seeds dried to $5 \%$ moisture content to temperatures below zero ${ }^{\circ} \mathrm{C}$, there was no leakage of cell content; the lumen was filled, though contracted (Figures $3 \mathrm{H}$ and $3 \mathrm{I}$ ). This can be explained due to the low moisture content, $5 \%$, of the seeds in these samples. The water in the seed consisted of only constitutional water and, consequently, did not form ice crystals (Marcos Filho, 2015).

According to Berjak and Pammenter (2013), the mechanical damage associated with reduction in cell volume is the most significant damage in highly hydrated tissues that undergo drastic drying procedures. By means of scanning electron microscopy, Faria (2005) observed retraction in cell volume related to the low physiological quality of Inga vera seeds in storage.

Removal of water from seeds can cause numerous ultrastructural injuries to cells, as for example, the denaturation of proteins, the crystallization of solutes, and damage in cell membranes and cell walls (Black; Pritchard,
2002). Thus, the ability to maintain cell integrity and to repair the damage caused by drying is of fundamental importance for seeds to maintain viability after drying. According to Borém et al. (2006) the type of drying results in different rates of water removal, which influences the damage caused to the cells.

An advantage of desiccation tolerant seeds is maintenance of cell wall flexibility during drying. The correct bending between the plasmatic membrane and the cell wall at the end of the seed maturation process is essential to prevent tissue damage (Vicré; Farrant; Driouich, 2004). This cell "bending" is related to the chemical composition of the membranes. Orthodox seeds have a high proportion of galactans and polysaccharides with arabinose, which act as plasticizers, increasing the flexibility of the cell walls and reducing strong interactions among polysaccharides (Jones; McQueen-Mason, 2004; Moore; Farrant; Driouich, 2008). In some orthodox seeds, the proportion of arabinose in the cell walls is extremely high, ranging from $38 \%$ to $60 \%$ (Shiga; Lajolo, 2006). In contrast, in seeds with recalcitrance characteristics, such as Coffea arabica, the proportion of arabinose is quite reduced, to approximately 20\% (Shiga; Lajolo, 2006).

In general, considering the contraction phenomenon, the ultrastructural pattern of the cells differs among the seed exposure temperatures and the moisture contents in the coffee seeds studied. In the seeds with the highest moisture content and best physiological quality that were not exposed to below zero temperatures, greater ultrastructural integrity was observed, and, in that treatment, the cells remained intact, i.e., swollen and with a filled lumen.

\section{CONCLUSIONS}

Coffee seeds with $40 \%$ moisture content and high physiological quality exhibit whole cells that are swollen and expanded and have a filled lumen, without signs of ultrastructural damage.

Drying of coffee seeds occasion contraction of the inner cell content. Drying of coffee seeds to $5 \%$ moisture content brings about drastic reduction in germination and intense contraction of cell volume.

Physiological and ultrastructural quality is compromised when seeds with moisture content of $40 \%$ are exposed to below zero temperatures, exhibiting absence of germination and empty cells.

\section{ACKNOWLEGEMENTS}

The authors express their thanks to Capes, to CNPq, to Fapemig, to Embrapa, to Consórcio Pesquisa Café and to UFLA for funding this study and for granting scholarships. 


\section{REFERENCES}

BERJAK, P.; PAMMENTER, N. W. Implications of the lack of desiccation tolerance in recalcitrant seeds. Frontiers in plant science, 22(4):1-9, 2013.

BHANDARI, K.; NAYYAR, H. Low temperature stress in plants: An overview of roles of cryoprotectants in defense. In: AHMAD, P.; WANI, M. (Eds.). Physiological Mechanisms and Adaptation Strategies in Plants Under Changing Environment. Springer, New York, NY, p.193-265, 2014.

BLACK, M.; PRITCHARD, H. W. Glossary. In: BLACK, M.; PRITCHARD, H. W. (Ed). Desiccation and survival in plants: Drying without dying. New York: CAB International, p.373-382, 2002.

BORÉM, F. M. et al. Qualidade do café submetido a diferentes temperaturas, fluxos de ar e períodos de présecagem. Coffee Science, 1(1):55-63, 2006.

BRASIL. Ministério da Agricultura, Pecuária e Abastecimento. Secretaria de Defesa Agropecuária. Regras para análise de sementes. Brasília, DF: MAPA: SDA, 2009. 395p.

CLEMENTE, A. C. S. et al. Preparo das sementes de café para a avaliação da viabilidade pelo teste de tetrazólio. Revista Brasileira de Sementes, 33(1):38-44, 2011.

COELHO, S. V. B.; ROSA, S. D. V. F.; FERNANDES, J. S. Cryopreservation of coffee seeds: A simplified method. Seed Science and Technology, 45(3):638-649, 2017.

DUSSERT, S. et al. Biologie de la conservation des semences de caféiers: Aspects fondamentaux et conséquences pratiques: une revue. Cahiers Agricultures, 21(2-3):106114, 2012.

ELLIS, R. H.; HONG, T. D.; ROBERTS, E. H. An intermediate category of seed storage behaviour?: I. Coffee. Journal of Experimental Botany, 41(9):11671174, 1990.

FARIA, J. M. et al. Changes in DNA and microtubules during loss and re-establishment of desiccation tolerance in germinating Medicago truncatula seeds. Journal of Experimental Botany, 56(418):2119-2130, 2005.

FERREIRA, D. F. Sisvar: A guide for its bootstrap procedures in multiple comparisons. Ciência e Agrotecnologia, 38(2):109-112, 2014.

FIGUEIREDO, M. A. et al. Exploratory studies for cryopreservation of Coffea arabica L. seeds. Journal of Seed Science, 39(2):150-158, 2017.
JONES, L.; MCQUEEN-MASON, S. A role for expansins in dehydration and rehydration of the resurrection plant Craterostigma plantagineum. FEBS Letters, 559(13):61-65, 2004.

JOSÉ, A. C. et al. Effects of drying rate and storage time on Magnolia ovate Spreng. seed viability. Seed Science and Technology, 39(2):425-434, 2011.

MARCOS-FILHO, J. Fisiologia de sementes de plantas cultivadas. 2. ed., Londrina: ABRATES, 2015. 660p.

MOORE, J. P.; FARRANT, J. M.; DRIOUICH, A. A role for pectin-associated arabinans in maintaining the flexibility of the plant cell wall during water deficit stress. Plant Signaling \& Behavior, 3(2):102-104, 2008.

PAMMENTER, N. W.; BERJAK, P. Physiology of desiccation-sensitive (recalcitrant) seeds and the implications for cryopreservation. International Journal Plant Science, 175(1):21-28, 2014.

SAATH, R. et al. Microscopia eletrônica de varredura do endosperma de café (Coffea arabica L.) durante o processo de secagem. Ciência e Agrotecnologia, 34(1):196-203, 2010.

SANTOS, M. A.; CHALFOUN, S. M.; PIMENTA, C. J. Influência do processamento por via úmida e tipos de secagem sobre a composição, físico-química e química do café (Coffea arabica L.). Ciência e Agrotecnologia, 33(1):213-218, 2009.

SHIGA, T. M.; LAJOLO, F. M. Cell wall polysaccharides of common beans (Phaseolus vulgaris L.): composition and structure. Carbohydrate Polymers, 3(1):1-12, 2006 .

SILVA, P. A. et al. Análise fisiológica e ultra-estrutural durante o desenvolvimento e a secagem de sementes de soja. Revista Brasileira de Sementes, 29(2):15-22, 2007.

UMARANI, R.; AADHAVAN, E. K.; FAISAL, M. M. Understanding poor storage potential of recalcitrant seeds. Current Science, 108(11):2023-2034, 2015.

VICRÉ, M.; FARRANT, J. M.; DRIOUICH, A. Insights into the cellular mechanisms of desiccation tolerance among angiosperm resurrection plant species. Plant, Cell \& Environment, 27(11):1365-3040, 2004.

WALTERS, C. Orthodoxy, recalcitrance and in-between: Describing variation in seed storage characteristics using threshold responses to water loss. Planta, 242(2):397406, 2015. 
WESLEY-SMITH, J. et al. Why is intracellular ice lethal? A microscopical study showing evidence of programmed cell death in cryo-exposed embryonic axes of recalcitrant seeds of Acer saccharinum. Annals of Botany,

115(6):991-1000, 2015.
WESLEY-SMITH, J. et al. Intracellular ice and cell survival in cryo-exposed embryonic axes of recalcitrant seeds of Acer saccharinum: An ultrastructural study of factors affecting cell and ice structures. Annals of Botany, 113(4):695-709, 2014. 